\title{
Evaluation of Mulching Practice on the Survival and Subsequent Early Growth Performances of the Transplanted Coffee Seedlings
}

\author{
Mohammedsani Amin ${ }^{1, *}$, Abera Jaleta ${ }^{2}$, Hika Bersisa ${ }^{1}$ \\ ${ }^{1}$ Oromia Agricultural Research Institute, Mechara Agricultural Research Center, Coffee and Tea Research Process, P. O. Box: 19, \\ Mechara, Ethiopia \\ ${ }^{2}$ Bedele College of Agricultural and Forestry, Metu University, Bedele, Ethiopia
}

Copyright $\bigcirc 2018$ by authors, all rights reserved. Authors agree that this article remains permanently open access under the terms of the Creative Commons Attribution License 4.0 International License

\begin{abstract}
The global temperature has been increasing over the years due to recurrent climate change and variability, which directly or indirectly affects the agriculture sector. This has made the necessary for the farmer to get the best out of the little rainfall. Therefore, the objectives of the present study were to identify effective mulching materials and their optimum application thickness for newly transplanted coffee seedlings. The field experiment was conducted during 2015 and 2016 at Mechara Agricultural Research Center (McARC) on-station and Sakina on-farm. Coffee seedlings of Mechara-1 variety and organic mulching materials of stalk of maize and vetiver grass at $5 \mathrm{~cm}$ and $10 \mathrm{~cm}$ mulching depth thickness were compared with farmers' practices of using soil as mulching material and no-mulch bare soils. The experiment was laid out in RCBD with three replications. Parameters such as seedling survival rate, soil moisture content, moisture stress score, weed density and subsequent early growth performance of the seedlings were studied. The result indicated that there are statistically significant differences $(p<0.05)$ among the treatment for most parameters studied at both locations and seasons. Vetiver grass mulches applied at $5 \mathrm{~cm}$ mulching thickness resulted in the highest combined over location and season percentage of coffee seedling survival rate (94.6\%), soil moisture content $(16.5 \%)$, the lowest moisture stress score (1.5) and the highest mean values of the different early growth measurement of coffee seedlings. However, weed species and their densities were lowest of all under coffee seedlings treated by stalk of maize mulches at $10 \mathrm{~cm}$ mulching depth. Therefore, from these results mulching newly transplanted coffee seedlings with vetiver grass at $5 \mathrm{~cm}$ mulching depth can be the recommended to farmers in moisture deficit areas as this practice conserved soil moisture resulting in better seedlings survival through increasing their tolerance to moisture stress.
\end{abstract}

Keywords Vetiver Grass, Maize Stalk, Survival Rate, Soil Moisture, Moisture Stress

\section{Introduction}

Coffee (Coffea arabica L.) is a non-alcoholic stimulant beverage crop that belongs to the family Rubiaceae and genus Coffea (CFC, 2004). Growing coffee provides income for about $25 \%$ of Ethiopia's population and is the country's top export (NPR, 2017). The country is the largest African producer of Arabica coffee. The crop is the backbone of the country's economy in which more than 15 million Ethiopians depend on it for a living (NPR, 2017). Coffee accounts for more than $25 \%$ of the GNP, $40 \%$ of the total export earnings, absorbing $25 \%$ of the employment opportunity for both rural and urban dwellers, and $10 \%$ of the total government revenue GDP (CFC, 2004).

Currently, the effects of climate change; higher temperatures and less rainfall could take a toll on the country's ability to farm this treasured crop. And the frequency of droughts has increased in recent years, affecting coffee growing regions as well. Ethiopia could lose from $39 \%$ to $59 \%$ of its current coffee-growing areas due to climate change by the end of the century (NPR, 2017). Despite the favorable climatic conditions, diversified genome and long history of its production in Ethiopia, coffee genetic erosion is increasing from time to time due to climate change. The traditional farmer depends entirely on rainfall as a source of moisture in all agricultural activities. But in the recent past, frequent droughts of varying degrees have been experienced in the tropics (Norman et al., 2011). According to the study, Ethiopia's coffee-growing areas could expand despite 
climate change, if farmers moved their farms to higher altitudes and adopted other mitigation strategies such as irrigating and mulching.

Currently, the most severe stress conditions (wilting and curling of leaves, loss of coffee crop, and plant death through drought) were recorded in the Hararghe coffee growing environments. In many Hararghe coffee gardens, cultivation appeared to be lacking suitable farming practices such as mulching and/ terracing or irrigation required for growing coffee in this area which, due to low rainfall, is not ideally suited to coffee production (Moat $e t$ al., 2017). One of the most important methods of moisture conservation is use of mulches. The use of mulch in coffee farms has been on the increase over the years especially during the first few years after transplanting seedlings (Addo, 2013). Mulching is the covering of the soil with different materials (e.g. grass, compost, manure) not only helps to preserve soil moisture and decrease soil temperature (reducing evapo-transpiration), but it can also increase soil fertility, suppress weeds, and improve rainfall penetration into the ground. Mulching has been used to good effect in Kenya, Tanzania and other countries in East Africa (Moat et al., 2017).

Hararghe is one of the areas currently under influence of climate change. It is moisture deficit area. In addition the tradition of using different mulching materials such as grass, maize straw, sorghum straw, banana leaves, wood barks, coffee husk and etc. is not well adapted by Hararghe coffee growing farmers. The mulching thickness of these materials is also not yet identified in the area. There is no any research output in the area for what type of mulch to apply and how much to apply. As a result of these problems early survival of transplanted coffee seedling is becoming the serous headache for coffee growing farmers of the area. Thus, scientific researchers are required to ascertain the precise outcomes and benefits of on-farm interventions, particularly terracing, mulching, irrigation, pruning, and shade management. Attention should also be paid to new and emerging technologies. So, moisture preservation at dry periods by different local mulch material in different thickness may be essential idea to survive coffee seedling after transplanting. Therefore this study was initiated with the objectives of identifying effective mulching materials and their mulching thicknesses that can improves the survival rate of newly transplanted coffee seedlings for increased productivity.

\section{Materials and Methods}

\subsection{Description of the Study Area}

The experiment was conducted at Mechara Agricultural Research Center (McARC) on-station and Sakina on-farm during 2015 and 2016 cropping seasons. Mechara is located $434 \mathrm{~km}$ to the east of Addis Ababa in Daro Labu district of west Hararghe Zone of Oromia Regional State. It has an altitude of 1760 m.a.s.l. with annual average temperature and rainfall $16^{\circ} \mathrm{C}$ and $963 \mathrm{~mm}$, respectively. The major soil type of the center is sandy loam clay, which is reddish in color. Sakina is $22 \mathrm{~km}$ away from Mechara and found at an elevation of 1711 m.a.s.l. It categorized as one of the lowland environments in the Daro Labu district.

\subsection{Experimental Materials, Treatments and Design}

The experiments at both locations were made up of four mulching treatments of Stalk of Maize and vetiver grass with different mulching thicknesses $(5 \mathrm{~cm}$ and $10 \mathrm{~cm})$. These treatments were compared with the usual soil mulching farmers' practices and no-mulch treatments. The treatments were arranged in randomized complete block design (RCBD) with three replications at both locations across the cropping seasons. Among the recently released Hararghe coffee varieties, Mechara-1 variety, which is recommended for the area, was used as a testing material.

\subsection{Experimental Procedure and Methods of Application}

Seedlings of Mechara-1 variety were raised in polyethylene bag at Mechara nursery site. After the seedlings grown and produce 8 true leaves, they were transplanted to the experimental fields in already prepared planting holes in the month of August 2015. The mulching treatment materials were applied at the end of September which is characterized by the termination of rainfall and start of dry season. The mulch treatments were kept under the seedlings until the commencement early belg rain (end of March 2015 and 2016). All other agronomic and cultural practices were uniformly applied to the treatments as per recommendations. The mulching materials were applied by spreading on the field $10 \mathrm{~cm}$ from the trunk of the tree as per its proposed treatment.

\subsection{Data and Methods of Collections}

Data of seedling survival rate, soil moisture content, moisture stress score, weed density and species and growth performance of the seedlings were collected from each treatment at different time intervals. The method of data collection was as follows:

\section{Coffee seedling survival rate}

The total numbers of survived and dead seedlings throughout the dry period from the time of mulching at the end of September 2014 to the beginning of rainy season (end of March 2015) were recorded for all treatments at both experimental locations. Then the percentage of dead seedlings from the total number of seedlings at early application of mulching materials per plot and treatments were calculated using the following formula: 
Survival rate (\%)

$=\frac{\text { No. of died seedlings at end ofdryperiod }}{\text { Total seedlings at early application of mulching }} X 100$

Soil moisture content

Soil sample were collected at a depth of $40 \mathrm{~cm}$ and fresh weight the soil sample were recorded using sensitive balance. These, soil samples were subjected to oven dry at $105^{\circ} \mathrm{C}$ for 72 hours. The dry weights of the oven dried soil samples were recorded to calculate the percentage of moisture content per plot and mulch treatments as follows: Soil moisture (\%)

$=\frac{\text { Fresh weight of soil }(\mathrm{gm})-\text { Dry weight of soil }(\mathrm{gm})}{\text { Dry weight of soil }(\mathrm{gm})} \times 100$

The soil moisture content data were recorded at 30 days interval throughout dry period from the end of September to March across the experimental years to determine the moisture conservation efficiency of each mulching treatment.

Moisture stress score (1-5 scale)

Moisture stress score is described as a morphological description of leaves of coffee seedlings at varying degrees of lack of moisture. It was recorded from all plant per plot twice per day early in the morning and late at noon at monthly interval for four consecutive times along with soil sample collection for soil moisture content measurement immediately after application of the mulching materials lasting throughout the dry period of each experimental season. A Scale of 1 to 5 was used to score the moisture stress where $1=$ all leaves green and turgid; $2=$ most leaves still turgid but younger leaves show leaf folding; $3=$ all leaves wilt or fold; $4=$ leaves partially turning pale and partly shed showing severe wilting; and $5=$ leaves completely turning brown, dry and mostly dropping.

Weed density and species

The number of weed and species emerged per plot was recorded twice before the application of mulching treatments and at the end of dry period. This was done by listing the names and counting the number of emerged weeds per species under three sample coffee seedlings which covered an area of $2500 \mathrm{~cm}^{2}$ per experimental plots.

\section{Seedling growth performance}

Coffee seedling growth performance data were recorded for total seedling height, stem diameter, (girth), number of primary branches, and canopy diameter from five representative seedlings/trees per plot as follows:

- $\quad$ Total height (TH) (cm): The length of the plant starting from the ground level to the tip of the tree on main stem was measured using tape meter.
- Girth $(\mathrm{mm})$ : the girth (stem diameter) of coffee tree on main stem was measured using digital caliper at $10 \mathrm{~cm}$ from the ground level.

- Number of primary branches (NPB): total number of primary branches was counted per tree.

- Canopy diameter $C D(\mathrm{~cm})$ : average length of tree canopy was measured from east-west and north-south direction, from the widest portion of the tree canopy.

\subsection{Data Analysis}

Analysis of variance (ANOVA) was computed for all collected data using GenStat $15^{\text {th }}$ edition. Treatment means were separated using fishery's protected least significant difference method (LSD) at 5\% probability level for statistical different means.

\section{Results and Discussion}

\subsection{Mulching Effect on Survival Rate}

The analysis of variance showed that statistically significant different percentage of seedlings survival across location in 2016 while non-significant different in 2015 cropping seasons. But, the combined analysis of variance across seasons and locations resulted in statistical different $(\mathrm{p}<0.05)$ for the measured percentage of seedling survival rates (Table 1$)$. The mean maximum $(98.3 \%)$ seedling survival rate was recorded on vetiver grass with $5 \mathrm{~cm}$ and $10 \mathrm{~cm}$ thickness and the minimum $(85.33 \%)$ was recorded under unmulched plot at Mechara. Similarly, at Sakina the mean maximum $(90.8 \%)$ and minimum $(66.5 \%)$ survival rate was recorded by vetiver grass of $5 \mathrm{~cm}$ mulching thickness and unmulched plot, respectively (Table 1).

The highest combined mean seedling survival rate (94.6\%) was recorded by coffee seedlings received vetiver grass at $5 \mathrm{~cm}$ mulching thickness across the growing season followed by the same mulching material with $10 \mathrm{~cm}$ mulching depth (Table 1). The least (75\%) seedling survival rate was recorded from the plots with no-mulch followed by the farmers' practices of using soil mulch. The reason for the highest seedling survival rates recorded under vetiver grass mulches at $5 \mathrm{~cm}$ mulching thickness could be due to the fact that the mulches allowed seedlings roots to extend, grow and establish deep in to the soil through conserving moisture compared to the bare soils. The result of the experiment is in line with that of Linda (2007) who reported seedling root development and density were greatest under organic mulches compared to bare soil. 
Table 1. Effect of mulching materials and thicknesses on survival rate of newly transplanted coffee seedlings during 2015 and 2016 at Mechara on-station and Sakina on-farm

\begin{tabular}{|c|c|c|c|c|c|c|c|}
\hline \multirow{3}{*}{ Treatment } & \multicolumn{6}{|c|}{ Survival rate $(\%)$} & \multirow{3}{*}{$\begin{array}{c}\text { Combined } \\
\text { mean }\end{array}$} \\
\hline & \multicolumn{3}{|c|}{ Mechara on-station } & \multicolumn{3}{|c|}{ Sakina on-farm } & \\
\hline & 2015 & 2016 & Mean & 2015 & 2016 & Mean & \\
\hline Stalk of maize with $5 \mathrm{~cm}$ thickness & 100 & $93.3 \mathrm{a}$ & $96.7 \mathrm{a}$ & 85.0 & $66.7 \mathrm{ab}$ & $75.8 \mathrm{ab}$ & $86.3 \mathrm{abc}$ \\
\hline Stalk of maize with $10 \mathrm{~cm}$ thickness & 100 & $88.3 \mathrm{ab}$ & $94.3 \mathrm{ab}$ & 83.3 & $66.7 \mathrm{ab}$ & $75.0 \mathrm{ab}$ & $84.6 \mathrm{abc}$ \\
\hline Vetiver grass with $5 \mathrm{~cm}$ thickness & 100 & $96.7 \mathrm{a}$ & $98.3 \mathrm{a}$ & 95.0 & $86.7 \mathrm{a}$ & $90.8 \mathrm{a}$ & $94.6 \mathrm{a}$ \\
\hline Vetiver grass with $10 \mathrm{~cm}$ thickness & 100 & $96.7 \mathrm{a}$ & $98.3 \mathrm{a}$ & 88.3 & $75.0 \mathrm{ab}$ & $81.7 \mathrm{ab}$ & $90.0 \mathrm{ab}$ \\
\hline Soil mulch (farmer practice) & 99.0 & $76.7 \mathrm{bc}$ & $87.8 \mathrm{bc}$ & 85.0 & $61.7 \mathrm{ab}$ & $73.3 \mathrm{ab}$ & $80.6 \mathrm{bc}$ \\
\hline Without mulch (control) & 96.7 & $74 \mathrm{c}$ & $85.3 \mathrm{c}$ & 85.0 & $48.0 \mathrm{~b}$ & $66.5 \mathrm{~b}$ & $75.9 \mathrm{c}$ \\
\hline Mean & 99.3 & 87.7 & 93.5 & 86.9 & 67.5 & 77.1 & 85.3 \\
\hline $\operatorname{LSD}(5 \%)$ & n.s & 13.4 & 6.4 & 13.7 & 32.1 & 21.2 & 12.3 \\
\hline CV\% & 1.9 & 8.4 & 3.8 & 8.6 & 26.2 & 15.1 & 7.9 \\
\hline
\end{tabular}

Means with the same letters in column are non-significant at 5\% probability level.

Table 2. Mean soil moisture content as affected by mulching materials and thicknesses under newly transplanted coffee seedlings at Mechara on-station and Sakina on-farm

\begin{tabular}{|c|c|c|c|c|c|c|c|}
\hline \multirow{3}{*}{ Treatment } & \multicolumn{6}{|c|}{ Soil moisture content (\%) by location and year } & \multirow{3}{*}{$\begin{array}{c}\text { Combined } \\
\text { mean }\end{array}$} \\
\hline & \multicolumn{3}{|c|}{ Mechara } & \multicolumn{3}{|c|}{ Sakina } & \\
\hline & 2015 & 2016 & Mean & 2015 & 2016 & Mean & \\
\hline Stalk of maize with $5 \mathrm{~cm}$ thickness & $11.1 \mathrm{a}$ & $10.7 \mathrm{c}$ & $11.0 \mathrm{~b}$ & $18.2 \mathrm{ab}$ & $8.4 \mathrm{bc}$ & $13.3 \mathrm{~b}$ & $12.1 \mathrm{bc}$ \\
\hline Stalk of maize with $10 \mathrm{~cm}$ thickness & $11.1 \mathrm{a}$ & $11.6 \mathrm{bc}$ & $11.4 \mathrm{~b}$ & $22.1 \mathrm{ab}$ & $8.4 \mathrm{bc}$ & $15.5 \mathrm{ab}$ & $13.3 \mathrm{~b}$ \\
\hline Vetiver grass with $5 \mathrm{~cm}$ thickness & $11.1 \mathrm{a}$ & $17.4 \mathrm{a}$ & $14.3 \mathrm{a}$ & $26.1 \mathrm{a}$ & $11.4 \mathrm{a}$ & $18.7 \mathrm{a}$ & $16.5 \mathrm{a}$ \\
\hline Vetiver grass with $10 \mathrm{~cm}$ thickness & $11.1 \mathrm{a}$ & $12.6 \mathrm{~b}$ & $11.9 \mathrm{~b}$ & $22.1 \mathrm{ab}$ & $8.8 \mathrm{~b}$ & $15.9 \mathrm{ab}$ & $13.7 \mathrm{~b}$ \\
\hline Soil mulch (farmer practice) & $10.1 \mathrm{a}$ & $8.73 \mathrm{~d}$ & $9.9 \mathrm{c}$ & $14.9 \mathrm{~b}$ & $7.2 \mathrm{~cd}$ & $11.1 \mathrm{~b}$ & $10.8 \mathrm{c}$ \\
\hline Without mulch (control) & $7.3 b$ & $7.48 \mathrm{~d}$ & $7.3 \mathrm{~d}$ & $14.9 \mathrm{~b}$ & $6.4 \mathrm{~d}$ & $12.9 \mathrm{~b}$ & $9.8 \mathrm{c}$ \\
\hline Mean & 10.3 & 11.4 & 11.0 & 19.7 & 8.4 & 14.6 & 12.7 \\
\hline LSD (5\%) & 2.7 & 1.7 & 1.31 & 10.7 & 1.4 & 5.3 & 2.6 \\
\hline $\mathrm{CV} \%$ & 14.4 & 8.4 & 6.6 & 28.9 & 9.5 & 20.3 & 11.4 \\
\hline
\end{tabular}

Means with the same letters in column are non-significant at $5 \%$ probability level.

\subsection{Effect of Mulching Materials and Mulching Thicknesses on Soil Moisture Content}

The present study indicated that there were statistically significant differences $(\mathrm{p}<0.05)$ among the mulching treatments across seasons at Sakina on-farm while 2015 results were statistically non-significant for McARC on-station (Table 2). Accordingly, at McARC the over year mean maximum $(14.3 \%)$ and minimum $(7.3 \%)$ moisture content were found in vetiver grass of $5 \mathrm{~cm}$ and without mulch treatments, respectively (Table 2). However, At Sakina, mean maximum $(19 \%)$ and minimum $(11 \%)$ value of soil moisture content were recorded by vetiver grass with $5 \mathrm{~cm}$ thickness and soil mulch, respectively. The thickness difference was also observed between vetiver grass in which vetiver grass of $5 \mathrm{~cm}$ was superior in moisture conservation than vetiver grass of $10 \mathrm{~cm}$ (Table 2).

The combined analysis of variance for soil moisture content, however, resulted in statistically differences across the cropping seasons and experimental locations (Table 2). Accordingly, statistically the maximum pooled mean percent $(16.5 \%)$ of soil moisture content across locations and seasons was recorded for soils of coffee seedlings mulched with vetiver grass at $5 \mathrm{~cm}$ mulching thickness, while the lowest $(9.8 \%)$ was under without mulch plots (Table 2). The present investigation is in line with that of Sinkevičienè et al. (2009) which indicated that mulched plots had higher soil moisture content than unmulched ones. Taparauskienė and Miseckaite (2014) also confirmed that the highest average soil moisture content was $18.0 \%$ in the plot mulched with straw, while the lowest $(16.2 \%)$ was in the plot without mulching. Further, Bert and Cregg (2009) also suggested that mulching increased soil moisture compared with no mulch. Moisture contents of soils under organic mulches of grass straw were higher than those in the control (Nkansah et al., 2003). This all shows that application of mulching 
materials is more advantageous in moisture conservation than bare soil. These might be due improved infiltration and reduced evaporation by mulching materials. High moisture in vetiver grass is also due to reduction in soil temperature. It is due to prevention of direct contact of solar radiation with the soil by the organic mulches which reduced water loss into the atmosphere through evaporation. Mulches also, reduce impact of raindrops and splash, thereby preventing soil compaction, reducing surface run-off and increasing water infiltration. All these combined to increase the soil moisture content and reduce moisture depletion.

\subsection{Effects of Mulching Materials and Mulching Thicknesses on Moisture Stress Score}

The analysis of variances revealed that, the response of coffee seedling under different mulching materials and mulching thicknesses to moisture stress is statistically significant differences $(p<0.05)$ among the mulching treatments across the experimental seasons at Sakina on-farm while the 2015 results were statistically non-significant for McARC on-station (Table 3). At Mechara on-station, the over year mean minimum stress score (1.3) and followed by vetiver grass of $10 \mathrm{~cm}$ (1.8) but statistically non-significant from each other. This mulching material had significant difference from unmulched and soil mulch treatments, in which maximum stress score of 2.2 and 1.8, respectively (Table 3) that showed low tolerance to drought stress during dry period. Similarly, at Sakina on-farm the average minimum (1.5) and maximum (2.8) score was recorded by mulching of vetiver grass of $10 \mathrm{~cm}$ thickness and soil mulch, respectively. Veivar grass is statistically significant from unmulched and soil mulch treatments. Thickness of $5 \mathrm{~cm}$ and $10 \mathrm{~cm}$ is non- significant from each other.

However, the combined analysis of variance for moisture stress resulted in statistically significant differences across the cropping seasons and experimental locations (Table 3). Statistically the least pooled mean (1.5) score of moisture stress across locations and seasons were recorded from coffee seedlings mulched with vetiver grass at $5 \mathrm{~cm}$ and $10 \mathrm{~cm}$ mulching thicknesses. This showed that, the ability of using vetiver grass as a mulching in drought tolerance is very essential in area where shortage of rain is headache for coffee growing farmers. Maximum drought tolerance of vetiver grass is correlated with moisture conservation ability of this material than other mulching types. Reduction in soil temperature is also the cause of drought resistance by vetiver grass.

Table 3. Effect of mulching materials and thicknesses on moisture stress tolerance for the newly transplanted coffee seedlings at Mechara on-station and Sakina on-farm

\begin{tabular}{|c|c|c|c|c|c|c|c|}
\hline \multirow{2}{*}{ Treatment } & \multicolumn{3}{|c|}{ Mechara } & \multicolumn{3}{|c|}{ Sakina } & \multirow{2}{*}{$\begin{array}{c}\text { Combined } \\
\text { mean }\end{array}$} \\
\hline & 2015 & 2016 & Mean & 2015 & 2016 & Mean & \\
\hline Stalk of maize with $5 \mathrm{~cm}$ thickness & $1.2 \mathrm{ab}$ & $2.4 \mathrm{~b}$ & $1.8 \mathrm{bc}$ & $2.9 \mathrm{bc}$ & $2.2 \mathrm{~b}$ & $2.6 \mathrm{~b}$ & $2.2 \mathrm{~b}$ \\
\hline Stalk of maize with $10 \mathrm{~cm}$ thickness & $1.0 \mathrm{a}$ & $2.1 \mathrm{ab}$ & $1.6 \mathrm{ab}$ & $3.2 \mathrm{c}$ & $2.2 \mathrm{~b}$ & $2.7 \mathrm{~b}$ & $2.2 \mathrm{~b}$ \\
\hline Vetiver grass with $5 \mathrm{~cm}$ thickness & $1.0 \mathrm{a}$ & $1.6 \mathrm{a}$ & $1.3 \mathrm{a}$ & $1.5 \mathrm{a}$ & $1.8 \mathrm{a}$ & $1.6 \mathrm{a}$ & $1.5 \mathrm{a}$ \\
\hline Vetiver grass with $10 \mathrm{~cm}$ thickness & $1.0 \mathrm{a}$ & $1.8 \mathrm{a}$ & $1.4 \mathrm{ab}$ & $1.6 \mathrm{a}$ & $1.5 \mathrm{a}$ & $1.5 \mathrm{a}$ & $1.5 \mathrm{a}$ \\
\hline Soil mulch (farmer practice) & $1.5 \mathrm{bc}$ & $2.0 \mathrm{ab}$ & $1.8 \mathrm{bc}$ & $3.2 \mathrm{c}$ & $2.4 \mathrm{bc}$ & $2.8 \mathrm{~b}$ & $2.3 \mathrm{~b}$ \\
\hline Without mulch (control) & $1.8 \mathrm{c}$ & $2.5 \mathrm{~b}$ & $2.2 \mathrm{c}$ & $1.8 \mathrm{ab}$ & $2.7 \mathrm{c}$ & $2.3 \mathrm{~b}$ & $2.1 \mathrm{~b}$ \\
\hline Mean & 1.27 & 1.98 & 1.66 & 2.08 & 2.22 & 2.17 & 1.74 \\
\hline $\operatorname{LSD}(5 \%)$ & 0.4 & 0.5 & 0.4 & 1.1 & 0.4 & 0.6 & 0.4 \\
\hline C.V(\%) & 21.9 & 14.2 & 13.7 & 26.5 & 10.1 & 15.7 & 11.2 \\
\hline
\end{tabular}

Means with the same letters in column are non-significant at $5 \%$ probability level.

Table 4. Total weed density and weed species emerged as affected by different mulching materials and thicknesses

\begin{tabular}{|c|c|c|c|c|c|c|}
\hline \multirow{2}{*}{ Treatment } & \multicolumn{3}{|c|}{ Weed species } & \multicolumn{3}{|c|}{ Weed densities } \\
\hline & Mechara & Sakina & Mean & Mechara & Sakina & Mean \\
\hline Stalk of maize with $5 \mathrm{~cm}$ thickness & $2.3 \mathrm{a}$ & $1.6 \mathrm{ab}$ & $2 \mathrm{ab}$ & $5.3 \mathrm{a}$ & $6.3 \mathrm{a}$ & $5.8 \mathrm{a}$ \\
\hline Vetiver grass with $5 \mathrm{~cm}$ thickness & $4.0 \mathrm{ab}$ & $2.3 \mathrm{ab}$ & $3.2 \mathrm{bc}$ & $12.0 \mathrm{a}$ & $4.0 \mathrm{a}$ & $8.0 \mathrm{a}$ \\
\hline Vetiver grass with $10 \mathrm{~cm}$ thickness & $5.7 \mathrm{bc}$ & $3.0 \mathrm{bc}$ & $4.3 \mathrm{~cd}$ & $15.3 \mathrm{a}$ & $7.7 \mathrm{ab}$ & $11.5 \mathrm{a}$ \\
\hline Without mulch (control) & $7.0 \mathrm{c}$ & $6.0 \mathrm{~d}$ & $6.5 \mathrm{e}$ & $41.7 \mathrm{~b}$ & $21.3 \mathrm{c}$ & $31.5 \mathrm{~b}$ \\
\hline Mean & 4.6 & 3.0 & 3.8 & 18.7 & 10.2 & 14.4 \\
\hline $\operatorname{LSD}(5 \%)$ & 2.9 & 2.1 & 1.8 & 17.6 & 12.1 & 10.3 \\
\hline $\mathrm{CV} \%$ & 34.4 & 37.6 & 26.2 & 51.8 & 37 & 39.5 \\
\hline
\end{tabular}

Means with the same letters in column are non-significant at $5 \%$ probability level. 


\subsection{Effects of Mulching Materials and Mulching Thicknesses on Weed Suppression}

The analysis of variances on weed species and density for growing seasons and locations showed statistically significant differences $(\mathrm{p}<0.05)$ among the mulching treatments (Table 4). Similarly, the combined analysis of variance for weed species and densities resulted in significant differences across cropping seasons and experimental locations (Table 4). Statistically the lowest mean number of weed species ( 2 and 2.3 ) and (0.3 and 1.6) were recorded in coffee seedlings mulched by stalk of maize at $10 \mathrm{~cm}$ and $5 \mathrm{~cm}$ thickness, respectively at both locations. But, weed densities were all low in coffee seedlings received either stalk of maize or vetiver grass at both mulching thickness compared to the farmers' practices of using soil as mulching material and the bare soil with no-mulch (Table 4). Similarly, the pooled means of both the number of weed species and their densities were significantly reduced in coffee seedlings mulched with both stalk of maize and vetiver grass for both thickness compared to the control mulching treatments, The present study was confirm the idea of Salman et al. (2015) who reported that, the minimum number and biomass of weeds was observed under cereal straw mulch and maximum in control treatment (without mulch). Edyta (2014) also founded that corn straw mulch significantly reduced weed infestation compared to the control plot without mulch. Similarly, Linda (2007) compared 15 mulch types that showed all of them significantly reduced weed growth as compared to bare soil, but there were no differences between types tested. Additionally, the protected soil habitat created by the use of mulches can increase beneficial organisms that prey upon weeds or eat their seeds.

Further, these studies is also similar to that of Dilipkumar et al. (1990), which says organic mulching reduces weed infestation and enhances growth and yield of crops. According to Nkansah et al. (2003) grass straw, rice straw, rice husk and saw dust mulches significantly reduced fresh weed weight. They also stated that grass straw mulch significantly reduced fresh weed weight while the highest fresh weed weight was observed in the control. Norman et al. (2011) stated that, dry grass and sawdust mulches suppressed weed growth significantly. This might be due to reduced weed growth is correlated with increased root growth and exploration by desirable plants. Mulches also reduce light, which will stress existing weeds and prevent the germination of many weed species. Smothering of weeds due to provision of soil cover by the organic mulches to cut off or lower light to weeds and their seeds in the soil by the mulch types might have accounted for efficient reduction in weed growth in both rainy and dry seasons. Also the mulch types acted as an obstacle to weed growth.

\subsection{Effects of Mulching Materials and Thicknesses on Seedlings Growth Performance}

The analysis of variance for early seedling growth performances showed statistically significant differences $(p<0.05)$ among the mulching treatments at Sakina on-farm across both cropping seasons (Table 5). Statistically the highest mean values for plant height, stem diameter (girth) and seedling canopy diameter were achieved for coffee seedlings mulched by vetiver grass at $5 \mathrm{~cm}$ mulching thickness in 2015 and 2016 but the highest seedling canopy diameter was also recorded under vetiver grass mulches at $10 \mathrm{~cm}$ mulching thickness in 2016 for the on-farm research experiment (Table 5). In contrast, statistically the highest mean number of primary branches was achieved by coffee seedlings treated with stalk of maize mulches at $5 \mathrm{~cm}$ and $10 \mathrm{~cm}$ mulching thickness in 2015 and Mulching of stalk of maize at $10 \mathrm{~cm}$ thickness in 2016 for Sakina on-farm. However, most of the mulch treatments are statistically at par among each other but superior to the no-mulch treatment control and farmers' practices of using soil as a mulching material to the growth performance parameters.

The analysis of variance for early seedling growth performances showed statistically significant differences $(p<0.05)$ among the mulching treatments in both 2015 and 2016 experimental seasons except for stem diameter (girth) in 2015 at McARC on-station (Table 6). All the mulching treatments showed statistically superior coffee seedling growth performances to the no-mulch and farmers' practices with vetiver grass mulching at $5 \mathrm{~cm}$ mulching thickness resulted in the highest measurements of the growth parameters (Table 6). The results of the study conducted at both experimental locations in 2015 and 2016 on the coffee seedling growth performances as affected by the mulching materials and thicknesses are in line with other similar studies (Linda, 2007; Manuel et al., 2000; Thakur et al., 2000; Norman et al., 2002; Nkansah et al., 2003; Gandhi and Bains, 2006; Moniruzzaman 2006; Awodoyin, 2007; Ojeniyi et al., 2007; Iftikhar et al., 2011; Dauda, 2012; Norman et al., 2011) who reported that mulching enhanced early growths of the transplanted seedlings through improving seedlings survival and enhancing root establishment of the seedlings as mulches provide improved soil moisture conservation, reduced soil temperature, reduced weed infestation and nutrient availability as a result of reduced leaching of nutrients.

In general from the present study superior total height, stem diameter, number of primary branch and canopy diameter was recorded by grass especially with $5 \mathrm{~cm}$ thickness. Enhanced growth of coffee by the mulched treatments could be attributed to the fact that mulching provides favorable conditions for growth and development of the plant by providing improved soil moisture conservation, reduced soil temperature, reduced weed infestation and nutrient availability as a result of reduced leaching of nutrients. 
Table 5. Early growth performance of newly transplanted coffee seedling as affected by mulching materials and thicknesses at Sakina on-farm during 2015 and 2016

\begin{tabular}{ccccccccc}
\hline \multirow{2}{*}{ Treatment } & \multicolumn{4}{c}{2015} & \multicolumn{4}{c}{2016} \\
\cline { 2 - 8 } & $\begin{array}{c}\text { PH } \\
(\mathrm{cm})\end{array}$ & $\begin{array}{c}\text { Girth } \\
(\mathrm{mm})\end{array}$ & NPB & $\begin{array}{c}\text { CD } \\
(\mathrm{cm})\end{array}$ & $\begin{array}{c}\text { TH } \\
(\mathrm{cm})\end{array}$ & $\begin{array}{c}\text { Girth } \\
(\mathrm{mm})\end{array}$ & $\begin{array}{c}\text { NPB } \\
\text { CD } \\
(\mathrm{cm})\end{array}$ \\
\hline Stalk of maize with 5cm thickness & $41.3 \mathrm{ab}$ & $6.33 \mathrm{~b}$ & $9.40 \mathrm{a}$ & $17.7 \mathrm{~b}$ & $80.7 \mathrm{ab}$ & $19.1 \mathrm{bc}$ & $20.3 \mathrm{abc}$ & $75.4 \mathrm{ab}$ \\
Stalk of maize with 10cm thickness & $38.6 \mathrm{ab}$ & $6.27 \mathrm{~b}$ & $9.40 \mathrm{a}$ & $19.5 \mathrm{~b}$ & $90.6 \mathrm{a}$ & $18.3 \mathrm{bc}$ & $23.9 \mathrm{a}$ & $73.0 \mathrm{ab}$ \\
Vetiver grass with 5cm thickness & $43.6 \mathrm{a}$ & $8.33 \mathrm{a}$ & $9.20 \mathrm{ab}$ & $27.4 \mathrm{a}$ & $90.4 \mathrm{a}$ & $23.4 \mathrm{a}$ & $21.4 \mathrm{ab}$ & $84.4 \mathrm{a}$ \\
Vetiver grass with10cm thickness & $39.6 \mathrm{ab}$ & $6.60 \mathrm{~b}$ & $8.93 \mathrm{ab}$ & $19.9 \mathrm{~b}$ & $91.9 \mathrm{a}$ & $19.6 \mathrm{ab}$ & $21.1 \mathrm{ab}$ & $85.9 \mathrm{a}$ \\
Soil mulch (farmer practice) & $29.8 \mathrm{bc}$ & $5.47 \mathrm{~b}$ & $8.13 \mathrm{ab}$ & $18.3 \mathrm{~b}$ & $73.9 \mathrm{~b}$ & $15.4 \mathrm{bc}$ & $18.5 \mathrm{bc}$ & $66.7 \mathrm{ab}$ \\
Without mulch (control) & $26.4 \mathrm{c}$ & $5.73 \mathrm{~b}$ & $6.87 \mathrm{~b}$ & $19.3 \mathrm{~b}$ & $74.0 \mathrm{~b}$ & $14.9 \mathrm{c}$ & $15.4 \mathrm{c}$ & $60.6 \mathrm{~b}$ \\
\hline LSD (5\%) & 11.54 & 1.44 & 2.4 & 5.23 & 14.48 & 4.39 & 5.27 & 22.94 \\
CV\% & 17.4 & 12.3 & 15.2 & 14.1 & 9.5 & 13.1 & 14.4 & 17 \\
\hline
\end{tabular}

Means with the same letters in column are non-significant at $5 \%$ probability level;

Key: PH=Plant height; NPB; number of primary branch; $\mathrm{CD}=$ Canopy diameter

Table 6. Early growth performance of newly transplanted coffee seedling as affected by mulching materials and thickness at Mechara on-station during 2015 and 2016

\begin{tabular}{|c|c|c|c|c|c|c|c|c|}
\hline \multirow[b]{2}{*}{ Treatment } & \multicolumn{4}{|c|}{2015} & \multicolumn{4}{|c|}{2016} \\
\hline & $\begin{array}{c}\mathrm{PH} \\
(\mathrm{cm})\end{array}$ & $\begin{array}{l}\text { Girth } \\
(\mathrm{mm})\end{array}$ & NPB & $\begin{array}{c}\mathrm{CD} \\
(\mathrm{cm})\end{array}$ & $\mathrm{TH}(\mathrm{cm})$ & $\begin{array}{l}\text { Girth } \\
(\mathrm{mm})\end{array}$ & NPB & $\begin{array}{l}\mathrm{CD} \\
(\mathrm{cm})\end{array}$ \\
\hline Stalk of maize with $5 \mathrm{~cm}$ thickness & $48.7 \mathrm{ab}$ & $9.6 \mathrm{a}$ & $8.4 \mathrm{ab}$ & $32.4 \mathrm{abc}$ & $80.7 \mathrm{abc}$ & $19.1 \mathrm{ab}$ & $20.3 \mathrm{abc}$ & $75.4 \mathrm{ab}$ \\
\hline Stalk of maize with $10 \mathrm{~cm}$ thickness & $42.7 \mathrm{ab}$ & $8.9 \mathrm{a}$ & $7.2 \mathrm{bc}$ & $31.3 \mathrm{abc}$ & $91.9 \mathrm{ab}$ & $18.3 \mathrm{ab}$ & $23.9 \mathrm{ab}$ & $73 \mathrm{ab}$ \\
\hline Vetiver grass with $5 \mathrm{~cm}$ thickness & $52.1 \mathrm{a}$ & $10.1 \mathrm{a}$ & $9.2 \mathrm{a}$ & $36.8 \mathrm{a}$ & $97.1 \mathrm{a}$ & $21.1 \mathrm{a}$ & $26.4 \mathrm{a}$ & $91.1 \mathrm{a}$ \\
\hline Vetiver grass with $10 \mathrm{~cm}$ thickness & $52.6 \mathrm{a}$ & $9.9 \mathrm{a}$ & $7.8 \mathrm{abc}$ & $35.7 \mathrm{ab}$ & $85.2 \mathrm{abc}$ & $19.6 \mathrm{ab}$ & $21.1 \mathrm{abc}$ & $79.3 \mathrm{ab}$ \\
\hline Soil mulch (farmer practice) & $40.9 \mathrm{~b}$ & 8.5 & $7 b c$ & $28.1 \mathrm{bc}$ & $77.2 \mathrm{bc}$ & $17.1 \mathrm{ab}$ & $18.5 \mathrm{bc}$ & $66.7 \mathrm{~b}$ \\
\hline Without mulch (control) & $39.3 b$ & $8.1 \mathrm{a}$ & $6.4 \mathrm{c}$ & $25.1 \mathrm{c}$ & $70.7 \mathrm{c}$ & $14.9 \mathrm{~b}$ & $15.4 \mathrm{c}$ & $57.3 \mathrm{~b}$ \\
\hline $\operatorname{LSD}(5 \%)$ & 11.11 & 2.6 & 1.9 & 8.57 & 18.24 & 5.05 & 6.95 & 23.35 \\
\hline CV\% & 13.3 & 15.5 & 13.8 & 14.9 & 12 & 15.1 & 18.3 & 17.4 \\
\hline
\end{tabular}

Means with the same letters in column are non-significant at $5 \%$ probability level.

Key; $\mathrm{PH}=$ plant height; NPB; number of primary branch; $\mathrm{CD}=$ Canopy diameter

\section{Conclusions and Recommendations}

The results of these experiments indicated that soil moisture content, survival rates of transplanted coffee seedlings, early growth performances, moisture stress score and weed suppression were significantly influenced by mulching materials and mulching thicknesses. Soil received vetiver grass mulch at $5 \mathrm{~cm}$ mulching thickness retained significantly the highest percentage of seedling survival rates $(94.6 \%)$ and soil moisture $(16.5 \%)$ compared to soils under no and soil mulches treatments. This mulching practice also significantly reduced the impact of moisture stress to the transplanted coffee seedlings resulting in the lowest moisture stress score of 1.5.

The mulching treatments also significantly affected the early growth performances of transplanted coffee seedlings wherever grass mulch at $5 \mathrm{~cm}$ mulching thickness achieved vigor growths. Superior pooled means of plant height, stem diameter (girth), number of primary branches and seedling canopy diameter were recorded by transplanted coffee seedlings treated with vetiver grass mulch at $5 \mathrm{~cm}$ mulching thickness. In general, the studies confirmed newly transplanted coffee seedlings by vetiver grass mulches at mulching thickness of $5 \mathrm{~cm}$ exhibited highest seedling survival rates, improved soil moisture contents, reduced moisture stress effects, vigor seedling growth performances and reduced weed infestations. Therefore, coffee growing farmers in Hararghe zone where rainfall variability causes moisture stress, the use of vetiver grass as mulching material at $5 \mathrm{~cm}$ mulching thickness through spreading of the grass at $10 \mathrm{~cm}$ away from the trunk of newly transplanted coffee seedlings/trees starting from end of September when rainfall terminates was recommended. Immediate demonstration and pre-scaling up activities should get due attention to take this result to the end users

\section{REFERENCES}

[1] Addo Norvis Komla, (2013). Effect of Organic Mulch on Growth and Yield of Sweet Pepper (Capsicum annuum L). 
Thesis Submitted To the University of Ghana, Legon in Partial Fulfillment of the Requirement for The Award of Mphil Crop Science Degree. Crop Science Department University of Ghana, Legon.

[2] Awodoyin, R. O., Ogbeide, F. I. and Oluwole, O. (2007). Effects of three mulch types on the growth and yield of tomato (Lycopersicon esculentum Mill.) and weed suppression in Ibadan, Rainforest-savanna Transi-tion Zone of Nigeria. Tropical Agricultural Research and Extension, 10.10.40308/tare.v10i0.187

[3] Bert M. and Cregg (2009). Weed control and organic mulches affect physiology and growth of landscape shrubs. Hortscience, 44(5):1419-1424.

[4] CFC (Common Fund for Commodities). 2004. Improving coffee quality in east and Central Africa through enhanced Processing practices; A (CFC/ICO/22) Project for Rwanda and Ethiopia, Final Appraisal Report. The Netherlands, Amsterdam. pp. 10-11.

[5] Dauda B.M. (2012). Effects of grassed and synthetic mulching materials on growth and yield of sweet pepper (Capsicum annum) in Mubi, Nigeria Journal of Agriculture and Social Sciences, 8: 97-99.

[6] Dilipkumar, G., Sachin, S. S. and Rajesh, K. (1990). Importance of mulch in crop production. Indian Journal of Soil Conservation, 18: 20-26.

[7] Edyta K. (2014). The effect of soil mulching with organic mulches, on weed infestation in broccoli and tomato cultivated under polypropylene fibre, and without a cover. Journal of Plant Protection Research, 54:2.

[8] Gandhi, N. and Bains, G. S. (2006). Effect of mulching and date of transplanting on yield contributing characters of tomato. Journal of Research. Punjab Agriculture, 43(1): 6-9.

[9] Iftikhar, A., Zahoor H., Shuaib R., Noor-Un- Nisa, M. and Summar, A. N. (2011). Response of vegetative and reproductive components of chili to inorganic and organic mulches. Pakistan Journal of Agricultural Science, 48(1): 19-24.

[10] Kader M.A, Senge M., Mojid M.A. and Ito K. (2017). Recent advances in mulching materials \& methods for modifying soil environment. Soil \& Tillage Research, 168: $155-166$

[11] Linda C. (2007). Impact of Mulches on Landscape Plants and the Environment: A Review. Journal of Environmental Horticulture, 25(4): 239-249.
[12] Manuel, C. P., Allison, M. D. and Stafford, M. A. C. (2000). Comparison of organic and synthetic mulch for bell pepper production at three levels of drip irrigation. Proc. Fla. State Horticulture Society, 113: 234-236.

[13] Moat, J., Williams, J., Baena, S., Wilkinson, T., Demissew, S., Challa, Z.K., Gole, T.W. and Davis. A.P. (2017). Coffee Farming and Climate Change in Ethiopia: Impacts, Forecasts, Resilience and Opportunities. -Summary. The Strategic Climate Institutions Programme (SCIP). Royal Botanic Gardens, Kew (UK). Pp. 37

[14] Moniruzzaman, M. (2006). Effects of Plant Spacing and Mulching on Yield and Profitability of mulch in arid region of India. Agrochemica, 31: 183-202.

[15] Nkansah, G. O., Owusu, E. O., Bonsu, K. O. and Dennis, E. A. (2003). Effect of mulch type on the growth, yield and fruit quality of tomato (Lycopersicon esculentum Mill). Ghana Journal of Horticulture. 3: 55-64.

[16] Norman, J. C., Asante, I. and Nartey, I. T. (2002). Mulching effects on growth, partitioning and yield of sweet corn. Ghana Journal of Horticulture. 1: 16 - 20.

[17] Norman, J.C., Opata, J. and Ofori, E. (2011). Growth and yield of okra and hot pepper as affected by mulching. Ghana Journal of Horticulture, 9: 35-42

[18] NPR (2017). Coffee Farmers Are 'On The Front Lines Of Climate Change' internet source at http://newsok.com/article/5553732

[19] Ojeniyi, S. O., Awodun, M. A. and Odedina, S. A. (2007). Effect of Animal Manure, Amended Spent Grain and Cocoa Husk on Nutrient Status, Growth and Yield of Tomato. Middle -East Journal of Scientific Research, 2(1): 33-36

[20] Salman A., Muhammad A.S.R., Muhammad F.S., Syeda S.Z., Imran H.K., Muhammad A., Abdulmanan S., Rashid I. and Muhammad S. Z. (2015). Mulching Strategies for Weeds Control and Water Conservation in Cotton. ARPN Journal of Agricultural and Biological Science, 10: 8.

[21] Sinkevičienè, A., Jodaugienè, D., Pupalienè R. and Urbonienè M.(2009).The influence of organic mulches on soil properties. Agronomy Research, 7(1): 485-491.

[22] Taparauskienè L. and Miseckaitė O. (2014). Effect of Mulch on Soil Moisture Depletion and Strawberry Yield in Sub-Humid Area. Pol. J. Environ. Stud., 23(2): 475-482

[23] Thakur P.S., Anju, T. and Kanaujia S. P. (2000). Reversal of water stress effects: Mulching impact on the performance of Capsicum annuum under water deficit. Indian Journal of Horticulture, 57(3): 250-254. 